\title{
MENAFSIR METAFORA DALAM KITAB HOSEA \\ Historis Kritis, Feminis, dan Ideologis
}

\section{ROBert SeTio*}

\begin{abstract}
The book of Hosea is one among a few books in the First Testament that gives rise to the diversity of interpretations. The text contains some language problems which prevent clear meaning. Its use of pornographic imagery as metaphor for the wrong doers has also provoked disagreements among the interpreters. Scholars throughout the ages have tried to look for the best way to receive the disturbing metaphor. By relating the Book with some historical circumstances, the metaphor is understood as representation of an historical reality, namely, the unfit leadership of the Israelite and Judahite communities. According to this interpretation, the use of sexual imagery should not bother the readers as it merely serves to convey the harsh criticism towards the community leaders who brought the society into chaos. However, feminist interpreters do not agree with such kind of interpretation. In their view, unravelling the ideology that allows such the use of metaphor that denigrate woman is the main task of interpretation. Their criticism has opened our eyes of how ideology plays significant roles in the production of the Book. The story of Hosea and Gomer should not be taken for granted as it results from a certain way of thinking. The view of the writer of the Book, for the feminists, is strongly misogynistic that it deserves severe criticism. While criticizing the gender imbalance view of the Book, the feminists seem to forget the main purpose of the metaphor. This writing wants to show that the metaphor is actually intended to alarm the worst socio-political situation. The blame of the socio-political turbulences is put on the shoulder of those whose view differs from that of the writer's. While blaming the opponents, the Book urges the acceptance of a dreamed society of the ideal.
\end{abstract}

* Dosen Fakultas Teologi Universitas Kristen Duta Wacana Yogyakarta. Email: robertsetio64@gmail.com

C ROBERT SETIO | DOI: 10.21460/gema.2017.21.292

This work is licenced under a Creative Commons Attribution-NonCommercial 4.0 International Licence. 
Keywords: metaphor, hitorical criticism, feminist interpretation, social crisis, ideology, dreamed society.

\section{Abstrak}

Kitab Hosea adalah salah satu dari kitab-kitab dalam Perjanjian Pertama yang menimbulkan kepelbagaian dalam penafsiran. Teks Hosea mengandung permasalahan bahasa yang mencegah kejelasan makna. Pemakaian gambaran pornografi sebagai metafora bagi mereka yang bersalah juga telah menimbulkan perbedaan pendapat di antara para penafsir. Para ahli dari berbagai zaman telah berusaha mengatasi persoalan-persoalan tersebut. Dengan menghubungkan teks dengan situasi-situasi sejarah, metafora dalam Kitab Hosea dijelaskan sebagai gambaran akan suatu realita sejarah, yaitu para pemimpin Israel dan Yehuda, yang dianggap tidak becus. Menurut model penafsiran yang seperti ini, pemakaian gambarangambaran seksual tidak harus mengganggu pembaca karena hal tersebut hanya digunakan sebagai sebuah kritik yang keras terhadap para pemimpin yang dianggap telah menyebabkan kekacauan dalam masyarakat. Tetapi, para penafsir feminis tidak setuju dengan argumentasi tersebut. Bagi mereka, tugas utama penafsiran adalah menguak ideologi yang membuat pemakaian metafora yang merendahkan perempuan itu dianggap sebagai hal biasa saja. Kritik para feminis tersebut membuka mata kita tentang bagaimana ideologi sangat berperan dalam pembuatan Kitab Hosea. Kisah Hosea dan Gomer tidak dapat dianggap sebagai hal yang biasa. Pandangan yang ada dalam Kitab Hosea memperlihatkan sikap misoginis yang perlu dikritik. Tetapi, pada saat melontarkan kritik terhadap pandangan yang tidak seimbang secara gender dari Kitab Hosea, para penafsir feminis justru melupakan tujuan utama dari metafora yang digunakan oleh kitab itu. Tulisan ini hendak memperlihatkan bahwa metafora tersebut bertujuan memperlihatkan sebuah keadaan sosial-politik yang kacau. Kekacauan ini kemudian diletakkan penyebabnya di atas pundak orang-orang yang berseberangan pandangan dengan penulis Kitab Hosea. Sembari melontarkan kesalahan pada para lawan, Kitab Hosea juga mendesakkan sebuah model masyarakat impian yang ideal.

Kata-kata kunci: metafora, historis kritis, penafsiran feminis, krisis sosial, ideologi, masyarakat impian. 


\section{PENDAHULUAN}

Kitab Hosea adalah salah satu kitab dalam Alkitab yang kontroversial. Kitab ini menceritakan tentang Gomer, seorang perempuan sundal yang dikawini oleh Hosea, seorang nabi, atas perintah Tuhan. Perkawinan dengan seorang sundal bagi seorang nabi seperti Hosea terlihat kurang pantas. Tetapi karena Tuhan yang memerintahkannya maka hal tersebut lalu menjadi sah. Keabsahan perkawinan ini bukan tanpa masalah. Para penafsir sepanjang zaman berdebat tentang perkawinan tersebut. Sebagian tidak ingin mempermasalahkannya, sebagian lain melihatnya sebagai masalah. Mereka yang tidak mempermasalahkan perkawinan tersebut beralasan bahwa perkawinan tersebut hanyalah sebuah simbol saja. ${ }^{1}$ Dalam hal ini, ketidaksetiaan Gomer menyimbolkan ketidaksetiaan Israel. Maka, tidak masalah jika Hosea harus mengawini Gomer yang seperti itu karena tujuannya adalah untuk menggambarkan hubungan Tuhan dan Israel yang tidak setia. Tetapi, para penafsir feminis tidak setuju dengan pandangan tersebut. Masalah utama yang menjadi sasaran kritik mereka adalah pemakaian perempuan sebagai simbol perbuatan yang tidak baik. Mengapa mesti memakai perempuan untuk menyimbolkan umat yang tidak setia? Selain itu, penafsir feminis juga mempersoalkan pandangan yang negatif tentang Gomer. Meksipun Gomer itu sundal, mengapa kesundalannya harus dipandang negatif?² Bahkan ada yang memuji-muji tokoh Gomer karena di tengah budaya yang merendahkan perempuan, dia berani untuk menyatakan kehendaknya (Hornsby, 1999).

Tulisan ini akan memperlihatkan bahwa fokus Kitab Hosea adalah pada ketidakdilan sosial yang kemudian menjadi sasaran kritiknya. Kritik terhadap Gomer yang adalah kritik terhadap Israel sebenarnya merupakan kritik terhadap ketidakadilan sosial. Jadi pandangan yang terlalu bertumpu pada Gomer, entah pada profesinya maupun pada keberadaannya sebagai perempuan, telah membuat kita gagal melihat fokus Kitab Hosea tersebut. Tulisan ini ingin mengajak kita kembali pada pemahaman bahwa Gomer dalam Kitab Hosea adalah metafora. Sebagai metafora ia tidak boleh dipersamakan dengan kenyataan. Kegundahan penafsir feminis tentang penggambaran Gomer dalam Kitab Hosea memperlihatkan bahwa mereka menganggap Gomer itu sama dengan perempuan yang nyata. Padahal Gomer adalah metafora dan karena itu perlu dipahami secara metaforis. Untuk tiba pada pemahaman mengenai kritik sosial tersebut, terlebih dahulu akan dijelaskan latar sejarah dari nabi dan Kitab Hosea. 


\section{LATAR SEJARAH}

Pembukaan Kitab Hosea memberikan indikasi waktu kapan Nabi Hosea bekerja. Hosea 1:1 menyebutkan bahwa Hosea bekerja pada zaman pemerintahan raja-raja Yehuda, yaitu: Uzia (783742 S.Z.B.), Yotam (742-735 S.Z.B.), Ahas (735-715 S.Z.B.), dan Hizkia (715-687 S.Z.B.). Juga pada zaman Raja Yerobeam bin Yoas atau Yerobeam II (786-746 S.Z.B.) $)^{3}$ dari Kerajaan Israel (Utara). Pada masa itu terjadi perang Siro-Efraimi di mana Yehuda di bawah kepemimpinan Ahas menolak untuk bekerja sama dengan Israel dan Siria dalam melawan Asyur. Penolakan itu berbuah penyerangan oleh Israel (yang juga dinamai Efraim) bersama Siria ke Yehuda. Pada masa yang sulit bagi Yehuda itu, orang Filistin dan Edom mengambil kesempatan untuk ikut menyerang Yehuda. Dalam keadaan terdesak, Ahas meminta bantuan Asyur yang akhirnya menyerang Israel dan Siria. Kitab Hosea pada umumnya mencerminkan keadaan yang kacau itu (Day, 2001: 598). Di dalam 2 Raja-raja 15 dikisahkan masa-masa di mana Israel bergonta-ganti raja karena perebutan kekuasaan dan hubungan dengan Asyur yang terkadang baik, terkadang diwarnai dengan pemberontakan. ${ }^{4}$ Pada akhirnya Asyur menguasai Israel dan menaklukkan Samaria, serta mendeportasi penduduknya pada tahun 722 S.Z.B. (Limburg, 1988: 7).

Hosea memiliki kemiripan dengan Amos. Keduanya bekerja di Israel (setidaknya pada masa Sang Nabi) dan melontarkan kritik atas ketimpangan-ketimpangan sosial yang terjadi pada masyarakat yang erat kaitannya dengan amoralitas penguasa. Tetapi sebagaimana dikatakan oleh John Day,

Whereas Amos had little hope for the future (Amos 9:11-15 is a later addition) and concentrated his invective on social injustice, corruption, and hypocritical religiosity, Hosea hoped for restoration after judgement and concentrated his anger on the religious syncretism of the Baalized YHWH cult and the political follies of coups d'etat and foreign alliances (Day, 2001: 571).

Meskipun Amos bekerja sebelum Hosea, namun kondisi Israel yang dilihat oleh Hosea tidak jauh berbeda dari yang disaksikan oleh Amos. ${ }^{5}$ Kalau Amos melihat berbagai ketidakadilan sosial terjadi di mana-mana akibat dari penyelewengan yang dilakukan oleh para elit penguasa, demikian juga yang kiranya dilihat oleh Hosea. Tetapi Hosea lebih cenderung menyoroti carutmarut yang terjadi sebagai akibat atau sesuatu yang berhubungan dengan peribadahan. Carole Fontaine menjelaskan situasi sosial politik tersebut demikian,

The book of Hosea accurately reflects the social and political turmoil that attended the last days of Israel. The heavy burdens of vassalage to Assyria were various and demoralizing, since the price of survival was greater than the simple payment of tribute. The draining away of resources from the vassal country worsened its economic situation automatically, since surpluses could not be amassed for normal trade, 
nor could profits be plowed back into the land. Large, wealthy landholders routinely passed their tax burdens to the crown along to the peasant tenants who worked their land. General indebtedness rose, small landholdings - the "heritage" of the poor — were swallowed up by greedy land speculators, and the ranks of the poor swelled. Similarly, the constant struggle to unite against Assyria, the Syro-Ephraimite war against Judah, and the court rivalries between pro- and anti-Assyrian factions also exacerbated the economic situation, since money siphoned away for militaristic reasons could not be used to improve the lot of the common folk (Fontaine, 1995: 45).

Hosea 7:11 berisi kritik terhadap pilihan penguasa Israel (kemungkinan Raja Hosea) yang memberontak terhadap Asyur dengan cara meminta bantuan pada Mesir. Bagi Hosea seharusnya Israel tunduk saja pada Asyur. Perbedaan pandangan politik tersebut membuat Hosea sangat kritis terhadap Israel. Kenyataan sejarah membuktikan bahwa pada akhirnya Israel hancur karena tidak sanggup melawan Asyur. Mesir yang diharapkan dapat menjadi pelindung, ternyata tidak mampu berbuat apa-apa. Kejatuhan Israel ini memperkuat penerimaan terhadap pesan kenabian Hosea. Kritiknya kepada penguasa Israel mendapatkan legitimasi sejarah. Sehingga ketika Hosea mengaitkan kritiknya dengan penyimpangan peribadahan, pandangan ini pun dengan mudah dapat diterima. Kehancuran Israel menjadi sebuah tragedi yang merupakan akibat dari penyimpangan agama.

Sebagaimana kitab-kitab kenabian atau kitab-kitab lainnya dari Perjanjian Pertama, Kitab Hosea mengalami beberapa tahap pengeditan, yang berarti juga rekontekstualisasi. Jadi Kitab yang kita punyai sekarang ini bukan, atau setidaknya bukan semua, berasal dari Hosea abad ke-8 S.Z.B. Penyebutan nama raja-raja Yehuda yang lebih lengkap ketimbang raja Israel di Hosea 1:1 tadi sudah merupakan bukti bahwa kitab ini lebih mengerti tentang situasi di Yehuda ketimbang Israel. Tadi sudah saya sebutkan bahwa sesudah Yerobeam II, masih ada raja-raja lain yang memerintah Israel sampai dengan kejatuhannya. Tetapi nama-nama raja yang disebutkan di 2 Raja-raja 15 itu tidak disebutkan di Hosea 1:1. Itu memperlihatkan bahwa pengetahuan penulis Kitab Hosea tentang raja-raja Israel kurang lengkap atau memang soal kerajaan Israel itu sengaja dipandang sebelah mata. Para ahli juga melihat bahwa pasal 1:1 itu menunjukkan peranan dari redaksi Deuteronomis (Schmid, 2012: 479). Pandangan Deuteronomis yang pro-Yehuda dan kurang positif tentang Israel membuat mereka lebih menonjolkan Yehuda.

Peranan mazhab Deuteronomis dalam peredaksian Kitab Hosea perlu menjadi perhatian dari para penafsir kitab ini. ${ }^{6}$ Mazhab Deuteronomis terbentuk sejak keruntuhan Israel. Ketika itu sekelompok elit Israel yang berasal dari golongan ningrat mengungsi ke selatan (Yehuda). Di sana mereka memperkenalkan model penyembahan kepada Yahweh yang eksklusif. Mereka mengkritisi penyembahan-penyembahan kepada Yahweh yang tidak murni. Pandangan puritan mereka 
membuat mereka tidak bisa menerima jika Yahweh disembah bersamaan dengan cara peribadahan Kanaan. Patung lembu emas yang sebenarnya dipakai sebagai lambang Yahweh dikecam oleh kaum Deuteronomis itu. ${ }^{7}$ Tempat peribadahan yang sangat disakralkan oleh orang Israel seperti Dan dan Betel dikritik habis-habisan oleh mereka. Kritik tersebut mereka buat ketika mereka berada di Yerusalem sesudah Israel hancur. Sebagai alternatif, mereka menekankan hanya peribadahan yang dilakukan di Yerusalem saja yang benar. Sentralisasi ibadah di Yerusalem merupakan propaganda yang mereka buat dengan penuh semangat. Gaung propaganda itu menggema sampai waktu yang lama. Para pembaca Perjanjian Pertama sekarang pun sangat dipengaruhi oleh pemikiran Deuteronomis yang sektarian itu. Yahweh digambarkan sebagai satu-satunya sesembahan bagi Israel/Yehuda. Yerusalem dipandang sebagai satu-satunya tempat ibadah yang benar. Apa saja yang di luar itu dianggap sesat.

Persoalan Deuteronomis adalah persoalan ideologis atau cara melihat. Fakta sosial apa pun sebenarnya tidak bisa dilihat apa adanya. Filter ideologis membuat orang melihat fakta yang sama dengan kesan yang berbeda. Dalam filter ideologi Deuteronomis, kekacauan sosial yang terjadi di Israel dan yang kemudian terjadi juga di Yehuda, tidak lain adalah akibat dari penyimpangan agama. Agama yang dalam pandangan Deuteronomis sudah tidak murni lagi adalah penyebab dari kejatuhan Israel dan kemudian Yehuda. Dalam Kitab Hosea, penyimpangan agama tersebut berulang kali diungkapkan. Pembaca Hosea hendak diyakinkan tentang kebenaran penyimpangan tersebut dan akibat-akibatnya. Hukuman tentang kehancuran Israel yang dilontarkan oleh Hosea adalah akibat dari kesalahan tersebut.

Proses pengeditan yang bertahap dan memakan waktu yang lama membuat konsistensi dalam Kitab Hosea kurang dapat dipertahankan. Dominasi berita penghukuman yang bila ditelusuri dampaknya tidak konsisten dengan isi berita pemulihan yang seperti pada kitab-kitab kenabian pada umumnya diletakkan pada bagian akhir kitab. Kesan tentang Yehuda di Kitab ini juga tidak selalu sama. Pada bagian-bagian tertentu seperti pasal 1:7 dan 4:15, Yehuda seperti belum mengalami kehancuran. Waktu yang bisa dibayangkan adalah sebelum 586 S.Z.B. Pada waktu itu Israel sudah musnah, sedangkan Yehuda masih ada. Sehingga ayat-ayat tadi masih melihat Yehuda yang selamat atau punya kesempatan untuk selamat. Psal 5:5; 6:11; 10:11 juga dapat dimengerti sebagai berita yang latarnya sebelum Yehuda ditaklukkan oleh Babel. Tetapi dalam kesempatan lain, sebagaimana Israel, Yehuda juga digambarkan sudah dalam keadaan hancur. Pasal 5:12-15, terutama 15, mengindikasikan Yehuda sudah mengalami nasib yang sama seperti Israel di mana penduduknya ditawan dan dideportasi. ${ }^{8}$ Sedangkan pasal 1:11 menggambarkan situasi pascapembuangan di mana baik Yehuda maupun Israel diharapkan akan dipersatukan kembali. 
Mengingat latar sejarah yang berbeda-beda itu Kitab Hosea telah menimbulkan berbagai macam penafsiran. Berkenaan dengan faktor kesejarahannya, ada penafsir yang melihat faktor tersebut sebagai penentu penafsiran terhadap Kitab Hosea. Artinya, Kitab Hosea harus ditafsir secara historis. Tetapi mengingat historisitasnya yang berlapis-lapis tadi, para penafsir tidak sepakat tentang latar sejarah yang mana yang harus dipakai untuk menafsir Kitab Hosea. Apakah latar sejarah abad ke-8 S.Z.B. di mana Sang Nabi hidup, ataukah pada zaman sesudahnya ketika pengikutnya memakai pikiran Sang Nabi untuk diterapkan pada konteks Yehuda? Bahkan ada ahli yang menempatkan latar sejarah itu pada masa Persia, yaitu sekitar akhir abad ke-6 S.Z.B. (Trotter, 2001). Sementara itu, ada pula penafsir yang tidak memedulikan historisitas Kitab Hosea tersebut dengan alasan Kitab ini tidak dimaksudkan untuk dimengerti oleh audience mula-mula. Alasannya adalah di dalam Kitab ini tidak ada indikasi mengenai audience yang dimaksudkan. Kalaupun ada indikasi latar sejarahnya, itu tidak otomatis mencerminkan tentang audience tertentu apalagi yang dikehendaki (intended). Alasan lain yang lebih mendasar adalah bahasa yang digunakan oleh Kitab Hosea. Kitab ini penuh dengan bahasa puitis dan metaforis. Bahasa seperti itu mencegah orang untuk tiba pada latar sejarah yang sesungguhnya. Bukan berarti tidak ada data sejarah yang digunakan, namun ketika data itu dikemas dalam sebuah ujaran puitis maka pemaknaannya tidak lagi bertumpu pada sejarah. Maka anjurannya adalah agar kitab ini dibaca sebagai sebuah metafora.

Saya sendiri berpendapat bahwa Kitab Hosea berangkat dari pengalaman-pengalaman riil yang membuatnya "terikat" pada kesejarahan. Tetapi seperti yang sudah saya uraikan tadi, kesejarahan Kitab Hosea tidak satu saja. Saya tidak setuju jika kitab ini hanya dibaca sebagai reaksi terhadap keadaan yang terjadi di Israel pada abad ke-8 S.Z.B. saja. Kecenderungan seperti ini sangat kuat terlihat pada tafsir-tafsir historis kritis. Konteks sejarah Kitab Hosea sangatlah beragam, sejalan dengan proses penggunaan dan pengeditannya yang membentang dari masa ke masa sampai setidaknya masa Persia. Keragaman konteks sejarah itulah yang membuat isi Kitab Hosea juga beragam. Sementara itu, pemakaian bahasa metaforis juga tidak mungkin diabaikan begitu saja. Entah apakah tokoh Gomer, bahkan Hosea itu benar-benar ada, namun setidaknya, perkawinan mereka yang kontroversial tersebut perlu dimengerti sebagai metafora. Apalagi jika kita melihat pasal 2 yang bahasanya porno itu (terutama ayat 3 dan 10). Kevulgaran ungkapan di pasal ini adalah dalam rangka mengungkapkan sesuatu secara metaforis. 


\section{TAFSIR FEMINIS DAN MASALAHNYA}

Kitab Hosea telah mendapatkan perhatian yang khusus dari para penafsir feminis. Kesadaran tentang hak-hak perempuan dan bagaimana perempuan seharusnya diperlakukan dengan adil oleh/ di hadapan laki-laki, membuat para penafsir feminis melihat penggunaan gambaran perempuan dalam Kitab Hosea bermasalah. Dalam buku A Feminist Companion to the Latter Prophets yang didedikasikan untuk membahas penggunaan metafora perempuan dalam kitab-kitab kenabian, khususnya Hosea, Athalya Brenner, editornya, mengatakan tentang Kitab Hosea demikian:

Clearly, the book exhibits a (male?) preoccupation, perhaps obsession, with things feminine and gender relations which are transformed into political and religious propaganda. The sociocultural impact of the androcentric views it contains cannot be underestimated (Brenner, 1995: 28)

Tetapi apakah yang menjadi obsesi tentang keperempuanan yang ada pada Kitab Hosea itu? Sudah barang tentu tidak jauh-jauh dari figur Gomer. Dalam Kitab Hosea, perempuan yang atas perintah Tuhan dikawini Hosea itu dengan jelas digambarkan sebagai perempuan yang tidak baik. Statusnya yang rendah itu justru dengan sengaja ditampilkan untuk memberikan tekanan pada maksud utama dari penggunaan kisahnya, yaitu sebagai perumpamaan keburukan orang Israel. Semakin jelek Gomer, semakin jelek pula Israel. Atau, bisa juga dikatakan sebaliknya, karena yang dikehendaki adalah menggambarkan kejelekan Israel maka karakterisasi Gomer juga harus jelek. Pilihan terhadap Gomer sebagai representasi Israel mungkin saja tidak dilihat bermasalah oleh penulis Kitab Hosea, namun tidak demikian di mata penafsir feminis.

Gomer dalam Kitab Hosea tidak pernah diberi kesempatan untuk bersuara. Citra negatif yang dikenakan kepadanya nampak tidak pernah dipertanyakan. Gomer seakan menerima saja penggambaran tentang dirinya. Di pasal 2, perempuan itu digambarkan sebagai istri yang tidak setia. Dia suka berselingkuh, sampai-sampai dia diancam untuk ditelanjangi di depan selingkuhanselingkuhannya, bahkan mungkin diperkosa di depan mata mereka (ay. 10). Perempuan itu benarbenar dipermalukan. Apakah yang sudah diperbuat perempuan itu? Kalaupun dia berbuat salah, apakah hukuman seperti itu tidak terlalu berlebihan? Kalaupun perempuan itu sudah sempat dipingit (ay. 6), namun tetap memberontak dengan melarikan diri untuk menemui selingkuhanselingkuhannya, pertanyaannya tetap, yaitu: apakah hukuman dilecehkan secara seksual di depan umum itu setimpal dengan perbuatannya?

Adalah wajar bagi kita untuk bertanya, mengapa istri Hosea itu sampai berbuat seperti yang diasumsikan di pasal 2 itu? Atau mungkin kita tidak pernah memikirkan pertanyaan seperti itu? Sebagai pembaca Kitab Hosea yang hidup dalam budaya yang sering memandang rendah 
perempuan, kita tidak pernah berpikir bahwa kalau ada perempuan yang berbuat seperti istri Hosea itu pasti ada yang tidak beres dengan rumah tangganya. Dalam budaya masyarakat kita, jika ada istri yang tidak setia kepada suaminya, pasti istri itu yang dipandang negatif. Bahkan ketika suaminya juga tidak setia, si istri tetap dipersalahkan. Kalau kedua-duanya selingkuh, si istri tetap dicap lebih negatif daripada suaminya. Sama-sama salahnya, namun kesalahan perempuan dinilai lebih besar daripada laki-laki. Tuduhan selingkuh juga punya arti yang lebih berat bila dikenakan kepada perempuan ketimbang laki-laki. Bila laki-laki selingkuh itu biasa, bila perempuan, itu jelek. Perempuan yang berselingkuh sering dilabeli dengan "perempuan nakal". Gomer pasti akan dilabeli sebagai "perempuan nakal" bila ia berada di tengah masyarakat kita. Maka sebagai pembaca, kita juga turut mendiamkan Gomer (dalam arti tutup mulut dan dalam arti membuat dia diam).

Tanpa informasi mengenai latar belakang perilaku Gomer, sebenarnya tidak adil jika dia langsung digambarkan secara negatif. Tetapi teks tidak memberi penjelasan yang sebenarnya penting itu. Para penafsir sering kali tidak melihat kediaman teks tentang alasan perbuatan Gomer sebagai hal yang perlu dipertanyakan. Mengapa? Karena mayoritas penafsir adalah laki-laki. Kalaupun ada yang perempuan, mereka terbiasa berpikir dengan cara laki-laki. Laki-laki tidak memiliki kepekaan terhadap perasaan perempuan. Dengan adanya penafsir-penafsir feminis, persoalan tersebut baru terkuak. Kritik feminis terhadap Kitab Hosea telah menyadarkan kita bahwa baik Kitab Hosea maupun para penafsirnya hidup dalam sebuah asumsi tertentu yang membuat mereka tidak merasakan bahwa penggambaran tentang istri Hosea itu tidak adil bagi perempuan.

Dalam dunia sosial Israel kuno, kedudukan perempuan lebih rendah daripada laki-laki. Tetapi masa itu memang berbeda dari masa sekarang. Pada waktu itu kesadaran tentang kesetaraan gender belum ada. Cara berpikir masyarakat masih sangat konservatif. Di tengah kondisi semacam itu, semua orang tahu apa yang harus diperbuat. Ketika sudah menikah, seorang perempuan akan membaktikan diri sepenuhnya kepada suami dan keluarganya. Istri akan dengan rela mengandung, melahirkan anak (terutama laki-laki) dan merawat anak demi kelangsungan kehormatan suami dan ayah mertuanya. Kita dapat membayangkan bagaimana patuhnya istri-istri di masa itu kepada suaminya. Tidak mungkin ada istri yang berbuat sekehendak hatinya sendiri. Segala yang dilakukan haruslah dalam pengetahuan dan demi kebaikan suaminya.

Oleh sebab itu, perilaku seperti Gomer itu sangat tidak lazim. Bagaimana kita harus menanggapi ketidaklaziman tersebut? Pada umumnya penafsir akan dengan mudah menghubungkan perilaku Gomer tersebut dengan profesinya. Karena dia seorang PSK maka perilakunya mesti liar. Tetapi, pandangan seperti ini keliru. Seorang PSK tidak mesti berperilaku buruk. Kita ingat 
kisah Tamar yang menyaru sebagai PSK di hadapan Yehuda, mertuanya (Kejadian 38). Tidak sekalipun kita dapati perilaku yang berlebihan dari Tamar. Justru karena perilakunya yang baik, Yehuda tertarik untuk "memakainya". Cerita itupun memperlihatkan bahwa yang buruk adalah justru Yehuda, bukan Tamar. Kita juga ingat akan cerita Rahab, seorang PSK di kota Yerikho yang menolong Yosua dan kawan-kawannya dari pengejaran raja Yerikho (Yosua 2). Rahab jelas menunjukkan seorang yang peduli dan mau melindungi orang yang dalam bahaya dengan cara yang sebenarnya sangat membahayakan dirinya.

Mengenai profesi PSK sendiri, Perjanjian Pertama tidak pernah mempersoalkannya. Memang Amsal 6 dan 7 menggambarkan perempuan sundal sebagai orang yang licik dan berbahaya. Tetapi kita tetap tidak mendapati nada yang menolak pelacuran di sini. Pesan yang diutamakan di sini adalah pentingnya pengetahuan, atau, kalau pakai bahasa kita sekarang, wawasan. Orang (laki-laki muda) yang kurang wawasan akan mudah terombang-ambing dan akhirnya jatuh. Salah satu (pasti bukan satu-satunya) yang bisa membuat orang jatuh adalah rayuan perempuan PSK. Sebenarnya pengambilan contoh perempuan PSK inipun juga bermasalah. Tetapi cukuplah untuk dikatakan di sini bahwa yang dimaksudkan oleh Amsal bukan memandang rendah pelacuran itu sendiri. Di Perjanjian Pertama satu-satunya yang dilarang untuk berhubungan dengan PSK adalah para imam seperti yang sudah saya sebutkan di bagian pendahuluan tadi. Tetapi itupun imamnya yang dilarang, bukan PSKnya.

Persoalan yang dikedepankan oleh para penafsir feminis itu adalah persoalan ideologis. Carol Fontaine, yang pernah menulis tafsir Hosea dengan metode historis kritis mengatakan,

If writing now, I would start with the bare notices in the text, and ask not, "What really happened?", but rather, "What does this mean within the text's ideological construction of reality, and what might it mean about the realities of women's lives, then and now?" (Brenner, 1995: 63).

Persoalan ini tidak terbatas pada Kitab Hosea saja. Teks-teks Perjanjian Pertama memperlihatkan bahwa pengarangnya memiliki ideologi yang membuat mereka tidak mempersoalkan pemakaian metafor perempuan yang negatif. T.D. Setel sebagaimana dikutip oleh Fokkelien van Dijk-Hemmes menjuluki gejala itu sebagai pornografi. Ciri-cirinya adalah,

1. Female sexuality is depicted as negative relative to a positive or neutral male standard.

2. Women are degraded and publicly humiliated.

3. Female sexuality is portrayed as an object of male possession and control. This includes the depiction of women as analogous to nature in general and the land in particular and, especially, in regard to imagery of conquest and domination (dalam Brenner, 1995: 248). 
Berkenaan dengan ciri yang ketiga itu perlu disebutkan tentang pendapat yang mengaitkan metafora perkawinan Hosea dengan ritus penyembahan dewa-dewi Kanaan. Sebagaimana dilihat oleh banyak penafsir dan sudah hampir menjadi konsensus bersama, kritik yang ada dalam Kitab Hosea kepada Israel telah dipahami sebagai kritik terhadap penyembahan Baal. ${ }^{9}$ Keberadaan Gomer, dalam pandangan ini, kait mengait dengan ritus penyembahan Baal yang menggunakan hubungan seksual. Ritus tersebut bertujuan untuk meminta kesuburan tanah atau tanaman agar dapat diperoleh hasil panen yang baik. Kitab Hosea dipandang tidak menyetujui ritus tersebut. Itulah sebabnya metafora dan bahasa yang dipakai sangat menjurus ke arah hubungan seksual. Dengan cara itu, Kitab Hosea hendak memperlihatkan kekonyolan dari ritus seksual dan sekaligus dewa yang disembah melalui ritus tersebut.

Pandangan semacam ini sebenarnya menolong kita untuk tidak jatuh pada penilaian yang negatif tentang perempuan. Kalau Kitab Hosea memakai perempuan sebagai simbol kesalahan, dalam pandangan ini, kesalahan tersebut bukan ditujukan kepada perempuan itu sendiri, namun kepada umat yang disimbolkan, yaitu Israel. Demikian juga dengan pemakaian gambaran porno tadi, yang dimaksudkan adalah ritus seksual dari penyembahan kepada Baal dan bukan pada perempuan yang dipandang negatif dalam gambaran porno itu. Tetapi para penafsir feminis tetap berkeberatan terhadap metafora-metafora tersebut. Bagi mereka dalam kasus seperti itu pun, perempuan tetap dirugikan. Alice Keefe bahkan melihat bahwa pengaitan pelanggaran seksual dari istri Gomer dengan ritus Kanaan memperlihatkan rendahnya penghargaan terhadap alam (Keefe, 2001). Jadi masalahnya bertambah, sudah merendahkan perempuan, masih merendahkan alam lagi.

Penafsiran feminis terhadap Kitab Hosea menolong kita untuk menyadari akan adanya asumsi-asumsi tertentu dari teks dan penafsirnya. Kesadaran tersebut menjadi penting karena pada akhirnya kita sendiri harus memberikan pertimbangan terhadap teks dan penafsirannya. Dengan kata lain, kita perlu menjaga jarak dengan teks dan penafsirannya. Sikap ini kita ambil bukan untuk mengecilkan arti teks, namun justru sebaliknya, agar dengan itu pemahaman kita akan teks dan penafsirannya semakin utuh. Tentu saja kita tidak bisa melepaskan diri dari penilaian subjektif kita sendiri. Seperti yang diperlihatkan oleh para penafsir feminis di atas, mereka cenderung menggugat pandangan-pandangan yang ada, baik dalam teks maupun penafsirannya yang dengan satu dan lain cara merendahkan martabat perempuan.

Tetapi penilaian subjektif terhadap teks dan penafsirannya tidak seharusnya membuat kita malah terjebak pada melebih-lebihkan pandangan kita sendiri. Kecenderungan seperti ini ada di kalangan penafsir feminis. Dalam menilai ideologi teks dan penafsirannya, para penafsir feminis 
cenderung hanya mengedepankan persoalan ketidakadilan terhadap perempuan saja. Bahwa perempuan sering kali digambarkan lebih rendah daripada laki-laki itu sulit dibantah. Tetapi untuk mengatakan bahwa hal tersebut dilakukan dengan sengaja, artinya, pengarang Alkitab mempunyai tujuan merendahkan perempuan, itu tuduhan yang terlalu berlebihan. Robert Carroll mengatakan,

From my point of view the use of metaphors of women for the community, nation, city, and land in the prophets may have little to do with the representation of women as such, just as the metaphorization of men for the community and the nation in the prophets may have little bearing on the representation of men as such. But from a feminist point of view apparently the two similar uses of metaphorization processes are not symmetrical. Furthermore, I would read the text and want to emphasize the fact that the metaphorization process reflected in it represents at best the point of view of a few male writers or of an ideological elite directed against the community (of men and, perhaps, of women). Feminists appear to want to insist on the extension of that point of view to include all men in the society producing the biblical texts. Hence any statement read in a male-generated text will be regarded as being contaminated by the interests of all males (dalam Brenner, 1995: 278-279).

Di mata Carroll, para penafsir feminis terlalu memukul rata tentang laki-laki. Apa-apa yang dilakukan oleh laki-laki langsung dianggap bias terhadap perempuan. Dengan begitu, para penafsir feminis menjadi tidak peduli lagi bahwa yang dirugikan bisa jadi tidak hanya perempuan, namun laki-laki juga. Upaya untuk menguak kesalahan yang dilakukan oleh para nabi, tidak hanya didasari prasangka terhadap perempuan, namun juga laki-laki. Para nabi mewakili pandangan tertentu yang tidak mewakili seluruh masyarakat. Ketidaksetujuan mereka terhadap pandangan tertentu lahir dari polemik, bahkan konflik, dengan kelompok lain yang berbeda pandangan. Maka, kalau ada pertentangan, pertentangan itu bukan antara laki-laki dan perempuan, namun antara kelompok tertentu dengan kelompok lainnya. Masing-masing kelompok bisa terdiri dari perempuan maupun laki-laki. Maka sikap kritis para penafsir feminis tersebut tetap perlu, namun arahnya bukan ditujukan pada persoalan gender tetapi pada bagaimana Kitab Hosea memotret lawan-lawan ideologisnya.

\section{MASYARAKAT IMPIAN}

Sebagai alternatif terhadap penafsiran feminis tadi, Kitab Hosea dapat dibaca sebagai sebuah desakan untuk membentuk sebuah komunitas/masyarakat yang ideal dengan ciri-ciri tertentu. Desakan tersebut perlu dilihat dalam bingkai polemik dengan para pemimpin dan mereka yang berseberangan pandangan dengan Hosea. Perlu kita ingat bahwa masyarakat ideal yang diperjuangkan Hosea ini masih belum ada. Justru yang ada adalah yang sebaliknya. Oleh karena 
itu, masyarakat ideal yang dicita-citakan Hosea masih merupakan masyarakat impian. Ciri-ciri dari masyarakat tersebut adalah sebagai berikut.

\section{Hidup Cukup}

Ayat-ayat seperti 2:8 dan 10:1 mengindikasikan kesejahteraan yang baik melalui hasil panen yang melimpah dan kekayaan yang diperoleh dari keberhasilan panen itu. Kondisi yang baik itu justru dipermasalahkan oleh Hosea. Tampaknya Hosea melihat kesuksesan materi tidak berjalan seiring sejalan dengan kesuksesan moral. Dengan memakai bahasa sekarang, kesuksesan materi tersebut adalah justru bukti dari keserakahan. Keserakahan tersebut membuat orang melupakan Yahweh. Padahal Yahweh adalah sumber dari kesuksesan tersebut. Sebagai hukuman dari dilupakannya Yahweh itu, 2:13 menyebutkan tentang pembalikan keadaan dari sejahtera ke keadaan seperti di padang gurun. Padang gurun itu dapat dipahami sebagai keadaan yang serba sulit. Mungkin yang dibayangkan adalah keruntuhan Israel dan kemudian Yehuda. Kedua kerajaan tersebut mengalami kemerosotan setelah mencapai masa puncaknya. Penaklukan Asyur dan Babel membuat Israel dan Yehuda seperti berada di padang gurun. Tetapi padang gurun sekaligus mengajar agar umat hidup cukup, tidak berlebihan, namun juga tidak kekurangan. Oleh karena itu, kita dapat menangkap bahwa yang dimaksudkan oleh Hosea adalah padang gurun itu lebih baik daripada hidup berkelimpahan. Bahkan ketika padang gurun itu berarti sebuah hidup yang penuh penderitaan, itu tetap lebih baik ketimbang hidup dalam kelimpahan namun membuat orang lupa akan Yahweh. Di 13:5-8 padang gurun dilukiskan seperti semacam tempat pendidikan bagi Israel untuk mengenal kekuasaan Tuhan.

\section{Hanya Yahweh Saja}

Pasal 2:15 dengan gamblang menunjukkan sikap anti terhadap percampuran sesembahan. Harapan yang dikehendaki adalah agar umat hanya menyembah Yahweh saja. Tadi sudah saya sebutkan tentang pengaruh pandangan Deuteronomis. Oleh Morton Smith, kaum ini disebut dengan kaum penyembah "Yahweh saja" (Yahweh alone party). Ketika berada di pembuangan, orang-orang Yehuda yang berada di tanah pembuangan di Babel mempunyai impian tentang kembalinya Kerajaan Israel Raya seperti di masa Daud. Orang-orang yang kemudian diizinkan kembali ke Yehuda itu menyatukan harapan politis tersebut dengan agama. Yahweh yang sudah dikenal sebagai allah nasional dipromosikan menjadi satu-satunya allah bagi orang Yehuda/Israel. Penyatuan allah menjadi jalan untuk menyatukan bangsa. Cita-cita untuk mendirikan kembali Israel Raya 
diperkuat dengan gagasan monoteistis tentang Yahweh. Meskipun tidak semua orang Yehuda setuju dengan padangan ini, namun dominasi pandangan ini sangatlah terasa. Penyingkiran allah atau model penyembahan lain yang tidak sejalan dengan pandangan tersebut merupakan jalan untuk memperkuat identitas kebangsaan.

Tidak saja tentang siapa yang disembah yang ingin diatur secara seragam, namun juga ritus-ritus penyembahannya. Pasal 4:12 melawan pemakaian cara-cara yang kalau dibahasakan sekarang menjadi klenik itu. Cara yang sebenarnya lazim untuk semua bentuk agama di masa itu maupun sekarang, dianggap "mengganggu” usaha pemurnian agama yang berarti juga Yehudaisasi atau Israelisasi agama. Agama Israel harus memiliki ciri khas yang bisa dibedakan dari agamaagama lainnya, yaitu tidak adanya cara-cara perdukunan. Selain itu, tentu saja, sentralisasi tempat ibadah sebagaimana disebutkan dalam 4:15.

\section{Nasionalistis}

Berkaitan dengan penyatuan agama yang sudah disebut di atas adalah penyatuan bangsa yang bila memakai istilah sekarang hal itu dapat dikategorikan sebagai etnosentrisme dan bahkan xenophobia. Hosea melontarkan kritik pedas pada kenyataan membaurnya orang Israel dengan bangsa-bangsa lain (7:8). Pembauran yang entah dilakukan di tanah Israel sendiri maupun di tanah asing (diaspora) merupakan bentuk pengaburan etnis yang sangat tidak diperkenan oleh Hosea.

Dalam konteks politik, ketika Israel berada di bawah ancaman bangsa lain pilihan untuk meminta bantuan asing juga dikritik oleh Hosea. Pasal 7:11 menyebutkan permintaan bantuan kepada bangsa-bangsa asing (Mesir dan Asyur) merupakan tindakan yang terlalu naif (harfiahnya: tidak mikir). Bangsa-bangsa besar tersebut diasumsikan tidak akan memberikan bantuan gratis. Dari sejarah kita tahu bahwa raja-raja Israel (dan Yehuda) tidak segan-segan untuk bekerja sama dengan penguasa asing untuk menjamin kelangsungan bangsanya. Asyur pernah menjadi tempat berlindung bagi Israel. Pada masa itu sebenarnya Israel justru bisa mendapatkan keamanan. Tetapi memang ada harga yang harus dibayar. Pasal 12:2b menyebutkan tentang upeti yang harus disetor kepada Asyur dan Mesir. Sebagai vassal state Israel patut memberikan upeti kepada negara yang melindunginya, namun dengan demikian mereka mendapatkan perlindungan. Sebagaimana pilihan politik pada umumnya, pilihan untuk menjadikan Asyur sebagai pelindung ada risikonya. Tetapi risiko itu ternyata lebih kecil ketimbang memilih berhadap-hadapan dengan Asyur. Terbukti ketika Raja Hosea memilih untuk melawan Asyur, Israel akhirnya kalah dan dihancurkan oleh Asyur.

Sikap anti-asing dari Hosea itu bahkan merambah sampai dengan ke masa lalu, yaitu ke masa nenek moyangnya sendiri, Yakub. Entah apa yang dipikirkan Hosea, namun di pasal 12:13 
Yakub yang mengambil istri seorang Aram juga dikritik. Padahal Yakub adalah cikal bakal Israel. Seharusnya dia dihormati. Tetapi Hosea nampaknya tidak memedulikan kehormatan Yakub. Itu memperlihatkan betapa kuatnya sikap xenophobic dari Hosea.

Berdasarkan sikapnya yang nasionalistis itu, Hosea membayangkan sebuah komunitas (imagined community) yang terdiri dari orang-orang yang jelas dan murni identitas kebangsaannya. Komunitas tersebut tidak dicemari oleh perkawinan atau bahkan mungkin pergaulan (kalau itu mungkin?) dengan orang asing. Tetapi agar komunitas semacam itu dapat diwujudkan maka diperlukan sebuah kepercayaan diri yang besar. Sebab tidak mungkin sebuah komunitas bisa dibangun secara eksklusif jika anggota-anggotanya tidak memiliki kepercayaan diri yang besar. Kepercayaan diri yang membuat mereka yakin dapat mengatasi masalah mereka sendiri tanpa bantuan pihak lain. Kalau ada hal positif yang bisa kita pelajari dari sikap etnosentris tersebut, hanya soal pembangunan kepercayaan diri (swadaya) itulah yang bisa kita ambil dalam konteks masyarakat kita sekarang ini. Tetapi bahaya dari pandangan semacam ini sudah sangat kita kenal sehubungan dengan maraknya konflik-konflik antar kelompok etnis dan agama dewasa ini.

\section{Solidaritas Sosial}

Sebuah komunitas ideal yang dibayangkan itu tidak cukup dibangun hanya dengan membuat pemisahan dari liyan. Komunitas tersebut juga harus dijamin keberadaannya di atas landasan moral. Pasal 4:2 mendaftarkan perbuatan-perbuatan amoral yang tidak diperkenan, seperti: mengutuk, berbohong, mencuri, dan sebagainya. Bunyi ayat ini menggemakan ketentuan Dasa Titah, terutama titah-titah yang mengatur relasi sosial. Pasal 7:1 menambahi pelanggaran moral tersebut dengan perbuatan kriminal. Situasi yang dibayangkan dalam ayat ini adalah semacam kekacauan sosial yang terjadi akibat tidak adanya pemimpin. Dari catatan sejarah kita tahu bahwa menjelang kehancuran Israel, kondisi masyarakat di negara itu diwarnai dengan kekacauan. Jadi ayat ini rupanya mengacu pada masa menjelang kejatuhan Israel itu. Tetapi keadaan yang buruk itu dikritik oleh Hosea dengan maksud agar tidak diulangi dalam masyarakat bayangan yang dicita-citakan.

Pasal 5:6; 6:6; dan 8:13 berisi kritikan terhadap kemunafikan agama. Orang hidup dalam kepura-puraan. Mereka menampilkan diri sebagai orang yang taat beragama dengan melakukan perintah-perintah agama dengan taat. Tetapi semua itu dilakukan secara "kulit luar" saja. Hosea mengatakan bahwa yang lebih penting bukanlah pelaksanaan ritus keagamaan, namun pengetahuan (da'ath) akan Allah (6:6). Istilah da'ath banyak kita dapati dalam kitab-kitab hikmat (Ayub, Amsal, dan Pengkhotbah). Istilah ini menunjukkan suatu laku yang sungguh-sungguh untuk mengenal Tuhan, yang tidak cukup hanya dengan melakukan ritual-ritual keagamaan saja. 
Hardikan Hosea ini sangat relevan untuk masyarakat kita sekarang yang nampak bersemangat sekali dalam menjalankan ritus-ritus keagamaan, namun di sisi lain, korupsi dan perbuatan amoral lainnya masih tetap mewabah di mana-mana, bahkan lebih besar tingkatnya ketimbang negaranegara sekuler.

\section{Pemimpin Agamanya yang Tulus dan Tidak Materialistis}

Masih berkaitan dengan soal kesalehan ritual yang dikritik Hosea tadi. Para pemimpin agama juga menjadi sasaran kecaman. Pasal 4:4 menunjukkan para imam yang tidak bonafide. Mereka tidak layak dijadikan tempat berkonsultasi tentang apa yang benar karena mereka sendiri melakukan kesalahan-kesalahan. Pasal 6:9 malah menyebutkan bahwa para imam itu saling menjatuhkan dan jatuh dalam seks bebas. Tampaknya para imam itu kurang menghargai kesucian pernikahan. Kalau begitu keadaannya maka kita dapat memahami mengapa Hosea begitu terobsesi terhadap persoalan seks. Rupanya karena dia mendapati banyaknya penyimpangan seks yang dilakukan oleh orang-orang yang seharusnya menjaga kesucian seks.

Yang menarik adalah di tengah kecaman-kecaman terhadap para pemimpin agama tersebut terdapat golongan rohaniwan yang diperkecualikan, yaitu nabi. Sebagaimana dikatakan dalam pasal 9:7-8 berikut, para nabi yang memberikan peringatan justru dianggap bodoh dan tidak digubris.

\footnotetext{
${ }^{7}$ Sudah datang hari-hari penghukuman, sudah datang hari-hari pembalasan, Israel akan mengalaminya,

"Nabi adalah seorang pandir, orang yang penuh roh adalah orang gila!", oleh karena besarnya kesalahanmu dan besarnya permusuhan:

${ }^{8}$ Efraim, umat Allahku, sedang mengintai nabi, jerat penangkap burung ada di sepanjang jalannya, permusuhan ada di rumah Allahnya.
}

Para nabi di Israel biasanya bekerja di istana. Tetapi tidak selalu mereka bersahabat dengan orang-orang istana. Hosea adalah salah satu nabi yang kritis terhadap istana. Dia juga tidak segan-segan mengecam para imam yang korup. Sikapnya tersebut membuat dia dimusuhi. Tetapi justru karena menolak mendengarkan Hosea maka Israel jatuh. Kejatuhan Israel adalah akibat perlawanannya terhadap para nabi. ${ }^{10}$

Gaung permusuhan antara nabi-nabi dengan imam-imam dan raja-raja menggema di hampir seluruh Alkitab. Dalam Injil-injil, Yesus juga digambarkan seperti seorang nabi yang sering melontarkan kritik kepada para pemimpin agama dan politik. Rupanya kebobrokan masyarakat tidak dapat dilepaskan dari kebobrokan para pemimpin agama dan politiknya. Sebagaimana Yesus, Hosea juga dengan lantang membuka borok-borok para pemimpin. 


\section{Kembalinya Negara Israel di Bawah Pimpinan Dinasti Daud}

Masyarakat yang diimpikan oleh Kitab Hosea masih merupakan masa depan yang dicitacitakan. Kita dapat membayangkan keadaan di masa pembuangan dan segera sesudahnya ketika muncul kerinduan akan berdirinya (kembali) sebuah Kerajaan Israel Raya. Pasal 3:5 dan 11:11 menggambarkan impian tentang kembalinya suku-suku Israel di tanah asal mereka. Tentu saja Israel yang baru itu adalah negara yang dipimpin oleh orang-orang yang tidak korup dan haus kekuasaan sebagaimana disebutkan dalam pasal 7:3-7. Para pemimpin yang tidak becus itu sebenarnya merupakan sasaran utama dari kecaman Hosea (juga di 5:1; 7:15). Sebagaimana sering dikatakan, kebaikan sebuah masyarakat bergantung pada para pemimpinnya. Bila pemimpinnya korup maka korup pula rakyatnya. Hosea tidak menghendaki masyarakat seperti itu, maka pilihannya adalah agar para pemimpin di negara baru itu nanti bukanlah pemimpin yang karakternya sama dengan pemimpin-pemimpin sebelumnya yang membawa Israel pada kehancuran.

Menarik untuk disimak, di tengah-tengah harapan akan kembalinya Kerajaan Israel Raya itu, ada pula nada kritis (kalau tidak mau dibilang menolak) terhadap sistem kerajaan. Ayat-ayat berikut berisikan suara anti-monarki itu:

\footnotetext{
Mereka telah mengangkat raja, tetapi tanpa persetujuan-Ku; mereka mengangkat pemuka, tetapi dengan tidak setahu-Ku $(8: 4)$.

Di mana gerangan rajamu, supaya diselamatkannya engkau, dan semua pemukamu, supaya diberinya engkau keadilan, hai, engkau yang berkata: “Berilah kepadaku seorang raja dan pemuka-pemuka!” Aku memberikan engkau seorang raja dalam murka-Ku dan mengambilnya dalam gemas-Ku (13:10-11).
}

Ayat-ayat tersebut menggemakan suara keberatan terhadap sistem kerajaan yang terdengar pada waktu kerajaan akan dibentuk (1 Sam. 8). Apakah yang dimaksudkan di sini adalah monarki dalam arti yang sebenar-benarnya ataukah hanya menunjuk kepada raja-raja yang buruk saja? Soal ini tidak bisa kita pastikan. Tetapi yang jelas, Kerajaan Israel Raya tidak pernah bangkit kembali. Yehuda memang sempat menikmati masa kemerdekaan di zaman pemerintahan keluarga Hasmoni (140-63 S.Z.B.). Meskipun dinasti ini mengenakan istilah kerajaan (basileus), namun kekuasaannya tidak dapat disetarakan dengan Kerajaan Israel Raya di masa Daud (meskipun kisah Alkitab mengenai kebesaran Kerajaan Daud ini juga tidak semuanya dapat dibuktikan secara historis). Apalagi dinasti Hasmoni hampir selalu berada di bawah bayang-bayang penguasa asing, yaitu pertama-tama Dinasti Seleukid yang Helenis itu, kemudian Romawi. Jadi, Kerajaan Daud yang diidam-idamkan itu tidak pernah menjadi kenyataan. Mungkin ayat-ayat anti-monarki tadi menunjukkan penerimaan pada kenyataan tentang tidak mungkin kembalinya Kerajaan Daud. 


\section{METAFORA TENTANG KEKACAUAN SOSIAL}

Kitab Hosea menyajikan sebuah bentuk masyarakat impian yang berangkat dari kritik terhadap masyarakat yang ada, baik di Israel maupun Yehuda. Masyarakat utopis itu merupakan kebalikan dari masyarakat yang nyata. Kita tahu bahwa masyarakat impian tersebut tidak pernah ada. Tetapi sebagai sebuah utopia, masyarakat yang diidam-idamkan itu tetap diperlukan, setidaknya untuk menjadi standar penilaian terhadap masyarakat yang ada. Meskipun demikian, pengenaan standar tersebut di luar konteks historis Israel yang sudah disebutkan di atas perlu dilakukan dengan berhati-hati. Dalam kesempatan ini, saya tidak akan masuk ke persoalan aplikasi Kitab Hosea ini. Tetapi sebagaimana sudah saya sebutkan sebelumnya, perhatian saya adalah pada bagaimana metafora Kitab Hosea sudah dimengerti selama ini. Khususnya, bagaimana para penafsir feminis memahami metafora tersebut.

Penjelasan di atas memperlihatkan perbedaan yang cukup besar antara penafsiran Kitab Hosea dari kacamata feminis dengan penafsiran yang menitikberatkan penggunaan metafora sebagai upaya untuk merekonstruksi masyarakat impian. Bila penafsiran feminis (setidaknya yang saya sebut tadi) lebih memilih untuk mempersoalkan penggunaan metafora seks yang dihubungkan dengan perempuan, dalam paparan sesudahnya, saya memilih untuk melihat Hosea sebagai penyusun konsepsi sebuah masyarakat ideal.

Dalam hal ini saya tidak sendiri. Seorang penafsir feminis yang kontribusinya juga ada dalam buku Brenner tadi, juga berpandangan serupa dengan saya. Alice A. Keefe dalam bukunya Woman's Body and the Social Body in Hosea mencoba untuk melampaui gaya penafsiran feminis yang baginya sering kali bercorak dualistis itu. Keefe mengkritik para penafsir feminis yang berasumsi bahwa persoalan seks adalah persoalan pribadi yang harus dipisahkan dari persoalan publik. Bagi Keefe,

\footnotetext{
Sexuality was not simply a private matter, but was "conceived of in broad terms spanning all the way from the sexual act itself to the extended family as its result, to the extended family's political-economic behavior" (Coote and Ord, 1989: 60). Rather than sex and the society signifying two separate spheres of human activity, in biblical literature, sexual activity carries profoundly social and political meanings (Keefe, 2001: 159).
}

Daripada menilai Kitab Hosea dengan sudut pandang modern yang membuat para penafsir feminis meradang, Keefe memilih untuk menempatkan perempuan sebagai bagian integral dari masyarakat Israel kuno. Keterkaitan antara perempuan dengan laki-laki dan masyarakat di mana mereka hidup sangatlah erat. Maka bila terjadi sesuatu pada perempuan, itu akan berimbas juga pada masyarakat. Sebaliknya, sesuatu yang terjadi pada masyarakat pasti akan berimbas pada perempuan. Setelah mengajak kita mengenali struktur sosial masyarakat Israel kuno itu, Keefe kemudian 
mengajak kita melihat penggunaan metafora perempuan dalam Kitab Hosea. Bagi Keefe, metafora istri Hosea dalam Kitab Hosea adalah petunjuk bagi kekacauan sosial. Dia mengatakan, "in a society structured around patrilineality, it is not difficult to see how female sexual trangression could be taken as a symbol for social chaos; by association, woman herself may come to symbolize chaos" (Keefe, 174). Sebagaimana bunyi judul bukunya, Keefe melihat tubuh perempuan sebagai simbol dari tubuh sosial. Dari situ Keefe lalu menghubungkan Kitab Hosea dengan sejarah yang memperlihatkan kekacauan sosial-politik di Israel. Sehingga perilaku istri Hosea yang kacau itu sebenarnya adalah penanda kekacauan sosial-politik di Israel.

Sedangkan James Trotter menempatkan Kitab Hosea pada konteks historis masa Persia. Kondisi Yehuda di masa itu penuh dengan gejolak. Di masa yang menentukan bagi pembentukan Yudaisme itu, Yehuda merupakan tempat di mana kelompok-kelompok yang berbeda pandangan teologis dan politik berebut pengaruh. Kaum hagolah yang pulang dari pembuangan, berusaha matimatian untuk mempromosikan kehidupan sosial keagamaan yang diatur secara ketat. Seperti yang juga sudah saya sebutkan di atas, kaum yang menuruni pandangan Deuteronomis, khususnya dari kelompok "hanya Yahweh", tidak sudi berkompromi dengan orang-orang yang bukan dari kelompok mereka. Sesama orang Yahudi yang bukan dari kelompok mereka dianggap sebagai warga negara kelas dua, bahkan semacam orang bukan Yahudi (nantinya menjadi orang Samaria). Sudah juga saya sebutkan tadi bahwa soal ini adalah soal ideologi. Dalam kenyataannya, sulit untuk mendapati orang Yahudi yang murni sebagaimana yang dikehendaki oleh kelompok "garis keras" tersebut (Trotter, 141). Bila Kitab Hosea dibaca dalam konteks polemik mengenai agama (dan politik) yang benar itu maka kita akan segera menangkap bahwa pemakaian metafora perempuan yang perilaku seksualnya berlebihan, seperti Gomer itu, tidak lain adalah penanda ketegangan-ketegangan antarkelompok yang terjadi di masa itu. Gomer adalah gambaran dari kelompok bukan hagolah yang bagi kaum hagolah sudah sangat sinkretistis dan tidak jelas identitasnya itu. Bagi kita yang tidak ikut dalam permasalahan mereka, pandangan hagolah tersebut tentu tidak objektif. Tetapi itulah ideologi. Orang bisa menjadi sangat tidak suka pada yang lain karena ideologi yang ada padanya.

\section{KESIMPULAN}

Kitab Hosea yang berisi metafora tentang perempuan yang berperilaku seksual berlebihan (atau menyimpang) itu perlu ditafsirkan dengan melihat konteks sejarahnya. Ketentuan ini tidak aneh dan tidak baru. Sudah lama para penafsir menggunakan pendekatan historis kritis untuk menguak sejarah yang menjadi latar Kitab Hosea. Tetapi penafsiran historis tersebut ternyata bermasalah. Para penafsir feminis memperlihatkan masalahnya, yaitu ketidakpekaan para penafsir terhadap 
kedudukan perempuan. Teks yang tidak merasa gamang dalam memotret perempuan dan seks sedemikian vulgarnya, tidak pernah mengejutkan para penafsir historis. Kritik feminis penting didengar agar pembaca dapat menyadari tentang diamnya perempuan yang dipertontonkan secara vulgar itu. Bagaimana perasaan Gomer? Pantaskah dia diperlakukan dengan sewenang-wenang seperti yang digambarkan oleh teks? Seharusnya persoalan itu diangkat oleh penafsir. Tetapi setelah mendengar penafsiran feminis, persoalan lainnya muncul. Penafsiran feminis nampak hanya memedulikan nasib perempuan saja. Penafsiran tersebut kurang melihat persoalan lain yang tidak kalah pentingnya, atau malah lebih penting lagi, yaitu kritik sosial. Kitab Hosea memang memakai metafora perempuan yang tidak baik, namun metafora itu hendak menunjuk pada kekacauan sosial yang terjadi. Bila demikian maka apakah yang ditawarkan oleh Kitab Hosea? Di balik kritik-kritik sosialnya, Hosea mengidam-idamkan sebuah masyarakat yang ideal. Masyarakat yang eksklusif dan murni. Bentuk masyarakat seperti itu membuat Israel jelas dengan identitasnya. Tetapi bagi kita yang hidup dalam masyarakat yang plural dan dengan kesadaran akan pentingnya pluralitas, masyarakat impian Hosea tersebut problematis.

Persoalan penafsiran ini memperlihatkan bagaimana sebuah teks seperti Hosea tidak bisa ditempatkan dalam ruang hampa. Teks berada dalam sebuah konteks sejarah yang membuat bahasa dan ekspresi yang digunakannya menjadi terbatas. Tugas penafsir adalah "mengembalikan" teks pada konteks sejarahnya itu. Dalam hal Hosea, pemakaian metafora perempuan yang vulgar itu perlu "dikembalikan" pada konteks sejarah di mana teks Hosea berada. Dalil ini bukan diajukan sebagai alasan untuk memaafkan (excuse) penggambaran yang tidak adil terhadap perempuan itu. Juga bukan untuk menutup-nutupi kevulgaran metafora itu. Tetapi agar metafora tersebut dapat lebih dipahami menurut konteksnya dan dengan demikian dapat lebih dihargai. Bagaimanapun teks mesti dimengerti sebagai sebuah sarana komunikasi yang menghubungkan penulis (atau editornya) dengan pembacanya. ${ }^{11}$ Atau bila hendak dilihat bahwa Hosea dan Gomer adalah orang-orang yang benar-benar pernah hidup di zamannya, maka apa yang terjadi pada mereka merupakan pesan yang hendak disampaikan kepada orang-orang yang hidup bersama mereka. Sebagai sarana komunikasi, metafora tersebut tentunya diharapkan dapat dengan mudah ditangkap oleh pihak-pihak yang dijadikan sasaran komunikasi. Maka meskipun dalam rasa orang sekarang metafora itu dianggap berlebihan, bagi audience Kitab Hosea di masa lampau, metafora itu cukup menyampaikan pesan tertentu. Maksudnya, persoalan perendahan terhadap perempuan seperti yang dilihat oleh penafsir feminis tadi, sangat mungkin bukan dianggap sebagai masalah oleh audience Hosea. Pastilah mereka merasakan "sengatan" dari metafora tersebut. Bagaimana mungkin nabi diminta mengawini seorang perempuan sundal dan bagaimana perasaan nabi itu ketika menuruti perintah Tuhan itu? Pertanyaan semacam ini tentunya ada dalam benak audience Hosea. Perasaan terganggu dari audience itu 
adalah memang sesuatu yang diharapkan. Tetapi bukan berarti audience di masa itu akan berpikir seperti para penafsir feminis tadi. Pandangan masyarakat di zaman itu belum seperti pandangan masyarakat sekarang yang sudah sangat peka terhadap ketidakadilan gender. Dengan mengatakan soal itu, saya tidak bermaksud menyepelekan kritik dari penafsir feminis. Kritik tersebut penting dan sudah seharusnya diperhitungkan oleh para pembaca kisah Hosea di masa sekarang. Tetapi itu berarti yang harus menjadikan metafora itu sebagai persoalan adalah kita yang hidup di masa sekarang. Teks Alkitab memang sudah selesai ditulis, namun belum selesai untuk ditafsirkan. Tugas penafsir tidak saja merekonstruksi pemaknaan teks pada masa lampau, namun melakukan apropriasi untuk pembaca sekarang. Usaha untuk melakukan apropriasi ini tidak bisa dilakukan begitu saja tanpa sikap kritis.

\section{Catatan}

${ }^{1}$ Bahkan ada pendapat dari para Rabi dan Bapa Gereja bahwa perkawinan itu hanya mimpi saja (Day, 2001: 571).

${ }^{2}$ Kata esyet zenunim diterjemahkan oleh LAI dengan 'perempuan sundal'. Istilah sundal dalam tuturan bahasa Indonesia mempunyai konotasi yang semata-mata negatif. Dalam Perjanjian Pertama, zenunim diterima biasa-biasa saja.

${ }^{3}$ Singkatan S.Z.B. merupakan kepanjangan dari Sebelum Zaman Bersama (Inggris: Before Common Era/B.C.E.), nama lain dari S.M. (Sebelum Masehi).

${ }^{4}$ Yerobeam II digantikan oleh Zakharia, anaknya, yang bertahta hanya dalam waktu 6 bulan sebelum dibunuh oleh Salum yang hanya berkuasa selama sebulan sebelum dibunuh oleh Menahem. Menahem memerintah 10 tahun lamanya dan bersedia memberikan upeti kepada Asyur. Pekahya anak Menahem melanjutkan kekuasaan ayahnya selama 2 tahun sebelum dibunuh oleh perwiranya sendiri, Pekah. Pekah memerintah selama 20 tahun. Di zamannya, Israel berperang melawan Yehuda. Hosea 5:8-15 kemungkinan merefleksikan peperangan tersebut (Day, 2001: 571). Pekah kemudian juga dibunuh oleh Hosea bin Ela yang mengambil alih kekuasaannya. Hosea, tidak seperti Pekah, pada awalnya bersikap pro-Asyur, namun kemudian berbalik dan memilih berlindung di bawah kekuasaan Mesir. Pada waktu itulah Asyur menyerang Israel/Samaria. Hosea 7:11 mengkritik sikap pro-Mesir itu yang akhirnya membawa kehancuran bagi Israel.

${ }^{5}$ Amos diperkirakan bekerja sekitar paruh pertama abad ke-8 S.Z.B.

${ }^{6}$ Moshe Weinfeld dalam bukunya Deuteronomy and Deuteronomic School memberikan penjelasan mengenai kesamaan paham antara Kitab Hosea dan Ulangan, antara lain sikap anti penyembahan asing dan cinta Tuhan kepada Israel (Weinfeld, 1994: 367, dst.).

${ }^{7}$ Belakangan ini para ahli meragukan klaim Alkitab bahwa dewa-dewi Kanaan disembah dengan simbol patung-patung binatang (theriomorfis). Tidak ada bukti arkeologis yang membenarkan tentang adanya patungpatung binatang itu.

${ }^{8}$ Deportasi penduduk melibatkan kelompok elit masyarakat, itu terjadi baik pada penaklukan Samaria oleh Asyur maupun Yerusalem oleh Babel. Rupanya orang-orang yang dibawa ke negeri penjajah adalah orang-orang yang memiliki keahlian yang dibutuhkan oleh negeri penjajah. Sisanya ditinggalkan di negeri asal.

${ }_{9}$ Penafsiran yang melihat Hosea sebagai perlawanan terhadap ritus seksual dalam penyembahan Baal menjadi diragukan karena tidak ada bukti-bukti arkeologis yang mendukung praktik semacam itu. Sementara itu, semakin diyakini bahwa Hosea mewakili pandangan kelompok Yahwisme yang menentang praktik peribadahan campuran di Israel (Utara). Tetapi pandangan kelompok ini belum menjadi dominan sebelum masa Helenis, yaitu sekitar abad ke-4 S.Z.B. (lih. Trotter, 2001: 120, dst.). 
${ }^{10}$ Tetapi Stephen Cook memperlihatkan bahwa Hosea sebenarnya berasal dari kelompok imam juga. Jadi yang terjadi adalah pertentangan antar-imam. Kelompok Hosea adalah imam Yahwisme (Cook, 1999).

${ }^{11}$ Terima kasih untuk masukan dari rekan Pdt. Yusak Tridarmanto, D.Th., tentang aspek komunikasi dari metafora ini.

\section{DAFTAR PUSTAKA}

Carroll, Robert P. 1995. "Desire Under the Terebinths: On Pornographic Representation in the Prophets-A Response", dalam A. Brenner, A Feminist Companion to the Latter Prophets, Sheffield: Sheffield Academic Press.

Cook, Stephen L. 1999. “The Lineage Roots of Hosea’s Yahwism”, Semeia, 87.

Brenner, Athalya. 1995. A Feminist Companion to the Latter Prophets, Sheffield: Sheffield Academic Press.

Fontaine, Carole. 1995. "Hosea”, dalam A Feminist Companion to the Latter Prophets, Sheffield: Sheffield Academic Press.

Day, John. 2001. "Hosea", dalam The Oxford Biblical Commentary, John Barton dan John Muddiman (eds.), Oxford: Oxford U.P.

Haddox, Susan. 2006. “(E)Masculinity in Hosea's Political Rhetoric”, dalam Israel's Prophets and Israel's Past, Brad E. Kelle dan Megan Bishop Moore (eds.), New York-London: T\&T Clark.

Hornsby, Teresa J. 1999. “Israel Has Become A Worthless Thing: Re-reading Gomer In Hosea 1-3", dalam Journal for the Study of the Old Testament, 82.

Keefe, Alice A. 2001. Woman's Body and the Social Body in Hosea, JSOTSS 338, London-New York: Sheffield Academic Press.

Kelle, Brad. 2005. Hosea 2, Metaphor and Rhetoric in Historical Perspective, Atlanta: SBL.

Limburg, James. 1988. Hosea-Micah, Interpretation, A Bible Commentary for Teaching and Preaching, Atlanta: John Knox Press.

Schmid, Konrad. 2012. "The Book of Twelve", dalam T\&T Clark, Handbook of the Old Testament, London-New York: T\&T Clark.

Trotter, James M. 2001. Reading Hosea in Achaemenid Yehud, JSOT SS 328, London-New York: Sheffield Academic Press.

Weinfeld, Moshe. 1994. Deuteronomy and Deuteronomic School, Indiana: Eisenbrauns. 